\title{
Review \\ Mechanisms of Chemopreventive and Therapeutic Proprieties of Ginger Extracts in Cancer
}

\author{
Mariia Zadorozhna and Domenica Mangieri *
}

Citation: Zadorozhna, M.; Mangieri, D. Mechanisms of Chemopreventive and Therapeutic Proprieties of Ginger Extracts in Cancer. Int. J. Mol. Sci. 2021, 22, 6599. https://doi.org/ $10.3390 /$ ijms 22126599

Academic Editor: Nam Deuk Kim

Received: 24 May 2021

Accepted: 17 June 2021

Published: 20 June 2021

Publisher's Note: MDPI stays neutral with regard to jurisdictional claims in published maps and institutional affiliations.

Copyright: (c) 2021 by the authors. Licensee MDPI, Basel, Switzerland. This article is an open access article distributed under the terms and conditions of the Creative Commons Attribution (CC BY) license (https:// creativecommons.org/licenses/by/ $4.0 /)$.
Department of Medical and Surgical Sciences, University of Foggia, Via Pinto 1, 71122 Foggia, Italy; mariia.zadorozhna@unifg.it

* Correspondence: domenica.mangieri@unifg.it

Abstract: Ginger (Zingiber officinale Roscoe, family: Zingiberaceae), originating in South-East Asia, is one of the most used spices and condiments for foods and beverages. It is also used in traditional medicine for many human disorders including fever, gastrointestinal complications, arthritis, rheumatism, hypertension, and various infectious diseases due to its anti-inflammatory, antioxidant, antimicrobial, and antiemetic properties. Intriguingly, many recent studies evidenced the potent chemopreventive characteristics of ginger extracts against different types of cancer. The aim of this work is to review the literature related to the use of ginger extracts as a chemotherapeutic agent and to structure the cellular and molecular mechanisms through which ginger acts in different cancer types. Data summarized from experiments (in vitro or in vivo) and clinical studies, evidenced in this review, show that ginger derivatives perpetrate its anti-tumor action through important mediators, involved in crucial cell processes, such as cell cycle arrest, induction of cancer cell death, misbalance of redox homeostasis, inhibition of cell proliferation, angiogenesis, migration, and dissemination of cancer cells.

Keywords: ginger extracts; chemoprevention; chemotherapy; natural compounds

\section{Introduction}

Cancer, being a multifactorial disease, is the second biggest cause of death in the world despite a great development of different types of its treatment [1]. Therapeutic options against cancer include surgical procedure, radiation therapy, chemotherapy as well as target and gene therapy [2]. Since the currently available treatment options are often accompanied by severe toxicity and side effects, consequently, researchers are consistently searching for new therapeutic solutions [3].

In this regard, $50 \%$ of approved cancer therapeutic agents are derived from natural products and, secondarily, medicinal plants metabolites have demonstrated a great perspective as a source of anticancer and chemopreventive compounds [4]. Composts isolated from edible plants have the advantage of low toxicity profiles and can simultaneously target multiple signaling pathways [5]. Therefore, dietary natural products can provide novel and fascinating preventive/therapeutic options for different kinds of neoplasia.

Ginger is known for having more than 60 active compounds, broadly divided into volatile and nonvolatile compounds [6]. Volatile components include hydrocarbons, meanwhile rhizome from ginger contains nonvolatile pungent phenolic compounds like 6gingerol, 6-shagol, 6-paradol, and zingerone [7] (Figure 1, Table 1). 

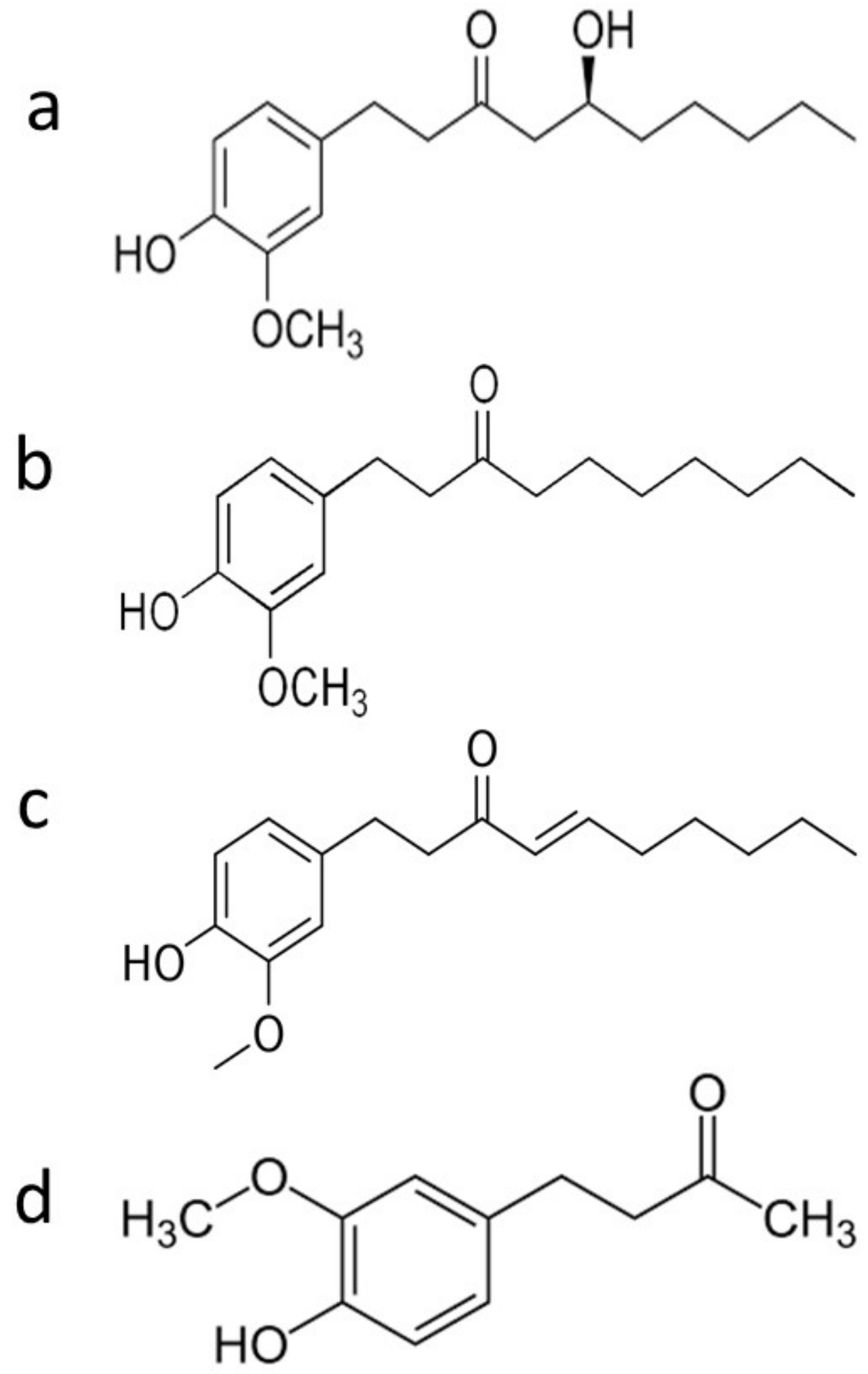

Figure 1. Chemical structure of main phenolic compounds of ginger: (a) 6-gingerol (1-[4'-hydroxy-3'-methoxyphenyl]-5hydroxy-3-decanone), (b) 6-paradol, (c) 6-shogaol, and (d) zingerone. 
Table 1. Chemopreventive activities of phenolic compounds of ginger.

\begin{tabular}{|c|c|c|}
\hline Phenolic Ginger Compounds & Chemopreventive Activities & References \\
\hline 6-gingerol & $\begin{array}{c}\text { Blockage of the cell cycle at G2/M phase; decrease of cells in the SubG0 } \\
\text { phase; depolarization and potential subsequent deterioration of the } \\
\text { mitochondrial membrane; induction of apoptosis; inhibition of } \\
\text { angiogenesis; induction of growth suppression; enhancement the } \\
\text { doxorubicin efficacy }\end{array}$ & [8-12] \\
\hline 6-paradol & Reduce blood glucose & [7] \\
\hline 6-shogaol & $\begin{array}{l}\text { Arrest of the cell cycle in G2/M phase; decrease levels of STAT3 and } \\
\text { NF-kB-regulated target genes including cyclin D1; induce apoptosis; } \\
\text { downregulation of surviving; decrease tumor volume and tumor burden; } \\
\text { restore wild type p53 function; provoke autophagy; inhibit phase I } \\
\text { enzymes (Cyt-p450 and Cyt-b5); increase phase II enzymes (GST, GR, } \\
\text { and GSH); reduce the cleavage of Notch1 }\end{array}$ & [13-17] \\
\hline Zingerone & $\begin{array}{c}\text { Inhibition of TGF- } \beta 1 \text { induced epithelial-mesenchymal transition, } \\
\text { migration, and invasion }\end{array}$ & [18] \\
\hline
\end{tabular}

These exact compounds have been studied for their anti-bacterial, antioxidant, and anti-inflammatory properties [19]. Ginger phenolic compounds especially have also shown anti-tumor properties [9,20,21] (Figure 2). In this review, we will more deeply discuss the chemopreventive molecular mechanisms of ginger derivatives including arrest of the cell cycle, induction of cancer cell death, misbalancing of redox homeostasis, inhibition of cell proliferation, angiogenesis, migration, and dissemination of cancer cells in different cancer types (Table 2, Figure 3).

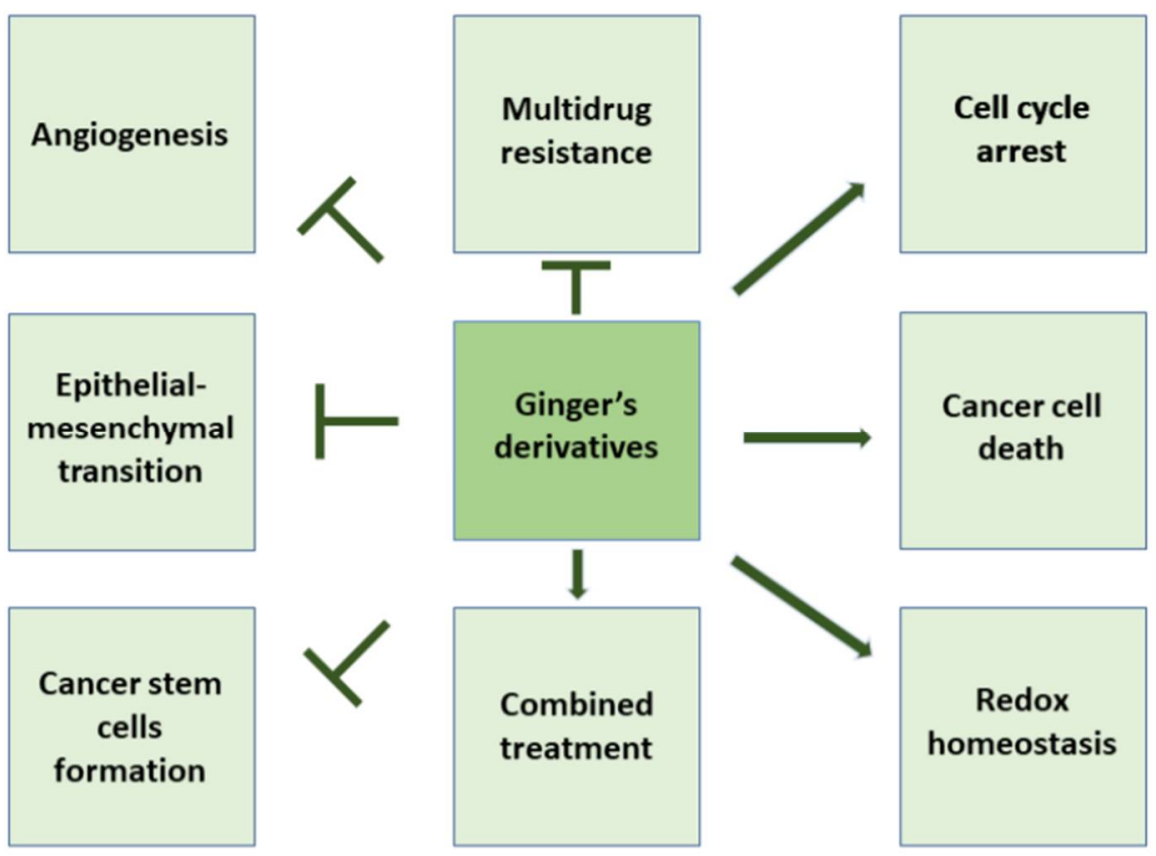

Figure 2. Schematic anti-cancer action of ginger and its phenolic derivatives. This natural compound reduces cancer cell proliferation, arrests cell cycle, causes an imbalance in cellular redox homeostasis, and induces cell death. Additionally, ginger derivatives inhibit angiogenesis, EMT, and CSCs. Furthermore, they decrease multidrug resistance and enhance chemopreventive effects. 
Table 2. Effects of ginger in different types of cancer.

\begin{tabular}{|c|c|c|}
\hline Tumor Entity & Functions of Ginger & References \\
\hline Breast cancer & $\begin{array}{c}\text { Blockage of the cell cycle at G2/M phase; Induction of typical } \\
\text { apoptotic changes in nuclear morphology, chromatin condensation } \\
\text { and fragmentation, membrane shrinkage and blebbing; enabled } \\
\text { autophagy followed by caspase-independent apoptosis; induction } \\
\text { of autophagy }\end{array}$ & {$[16,18,22]$} \\
\hline Prostate cancer & $\begin{array}{c}\text { Arrest of cell cycle in the G1 phase with subsequent decrease in S and } \\
\text { G2/M through p21 dependent pathway; downregulation of MRP1 } \\
\text { and GST-protein expression }\end{array}$ & {$[23,24]$} \\
\hline Ovarian cancer & $\begin{array}{l}\text { Suppressed production of NF- } \mathrm{B} \text { B regulated angiogenic factors; p53 } \\
\text { stimulation of apoptosis through Bcl-2 elimination }\end{array}$ & {$[25,26]$} \\
\hline Colon cancer & $\begin{array}{c}\text { Arrest of cell cycle at different check points by inhibition of cyclin } \\
\text { dependent kinases and activation of cell cycle check points; } \\
\text { upregulation of p21 expression; reverse of EMT to } \\
\text { Mesenchymal-epithelial transition (MET) through the upregulation } \\
\text { of miR-200c }\end{array}$ & {$[17,19,27,28]$} \\
\hline Hepatocellular carcinoma & $\begin{array}{l}\text { Arrest of cell cycle at the G2/M phase; inhibition of the } \\
\text { PI3K/AKT/mTOR and STAT3 signaling pathways; inhibition of Bcl-2 } \\
\text { expression and up-regulation of Bax, cytochrome c, caspase-9 and -3 } \\
\text { protein expressions }\end{array}$ & {$[21,29]$} \\
\hline Gastric adenocarcinoma & $\begin{array}{c}\text { Interruption of cell cycle at different check points; mediation of } \\
\text { mitochondrial pathway of apoptosis; } \\
\text { unbalance ROS homeostasis and induction of apoptosis }\end{array}$ & {$[30]$} \\
\hline Non-small lung epithelium cancer & $\begin{array}{c}\text { The loss of mitochondrial membrane potential of that leads to } \\
\text { increase in Bax/Bcl-2 ratio and activation of mitochondrial } \\
\text { death cascade }\end{array}$ & {$[31,32]$} \\
\hline Melanoma & $\begin{array}{l}\text { Induction of caspase independent cell death via the inhibition of } \\
\text { ERK1/2, p38 and Akt signaling pathway }\end{array}$ & [33] \\
\hline Endometrial adenocarcinoma & $\begin{array}{l}\text { Induction of apoptosis by increasing the expression of p53 and Bax } \\
\text { and simultaneously decreasing the expression of Bcl-2 }\end{array}$ & {$[34]$} \\
\hline Cervical cancer & $\begin{array}{l}\text { Induction of typical apoptotic changes in nuclear morphology, } \\
\text { chromatin condensation and fragmentation, membrane shrinkage } \\
\text { and blebbing }\end{array}$ & [35] \\
\hline Lung cancer & $\begin{array}{c}\text { Sensitization of TRAIL-induced apoptosis by inhibiting } \\
\text { autophagy flux }\end{array}$ & [36] \\
\hline Head and neck squamous carcinoma & $\begin{array}{l}\text { Increase in apoptotic death by downregulation of surviving; } \\
\text { inhibition of mutant p53 Bcl-2 expression, and increased expression } \\
\text { of Bax, regulation of Bax/Bcl-2 ratio which induce cell apoptosis }\end{array}$ & {$[37,38]$} \\
\hline Pancreatic cancer & $\begin{array}{c}\text { Activation of AMPK, a positive regulator of autophagy, and } \\
\text { inhibition mTOR, a negative autophagic regulator; unbalance ROS } \\
\text { homeostasis and induction of autosis }\end{array}$ & [39] \\
\hline
\end{tabular}




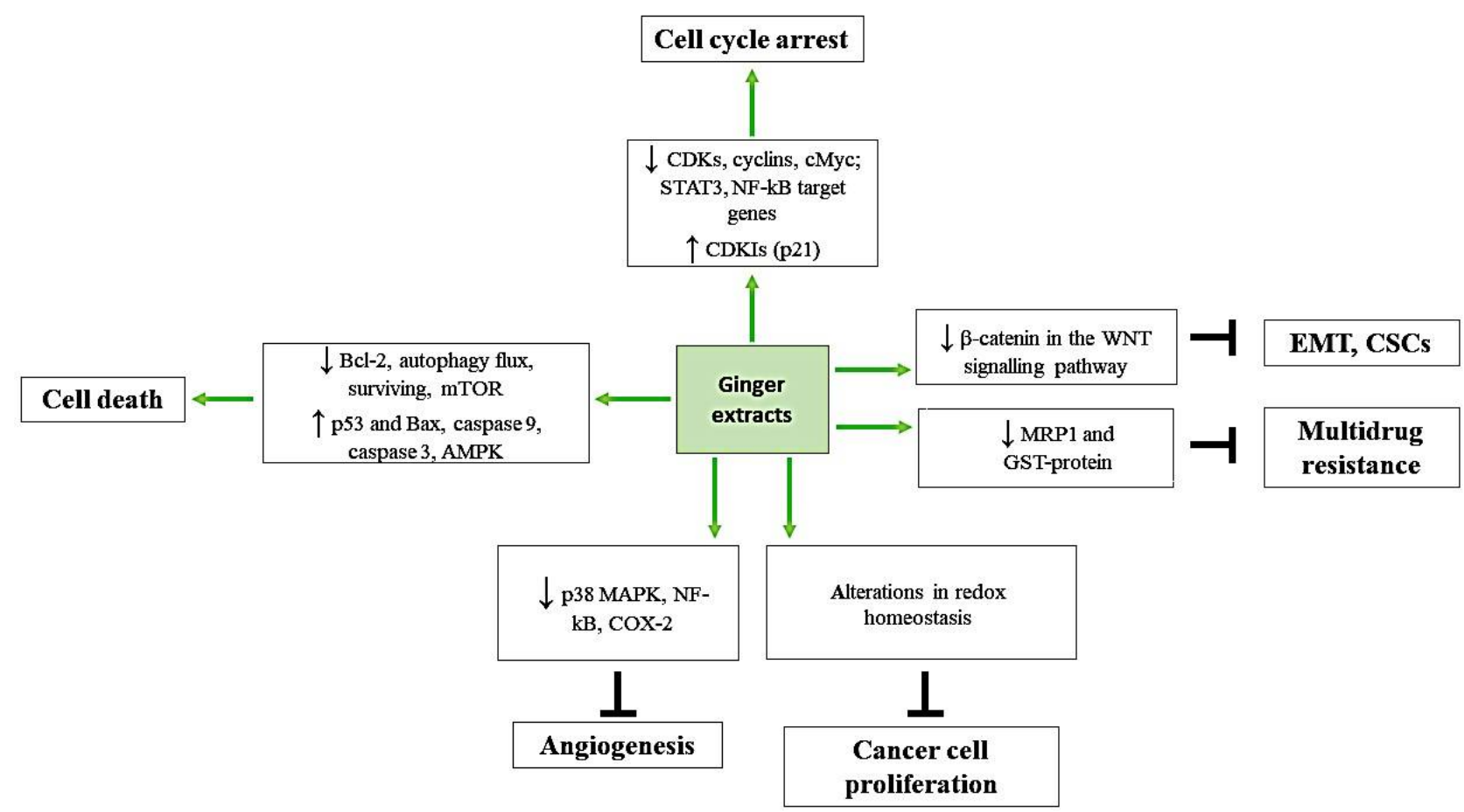

Figure 3. A schematic diagram showing main molecular targets of ginger derivatives. The natural compound participates in the cell cycle arrest by inhibiting the expression of cyclins, CDKs, and levels of STAT3, NF-kB target genes, and by activation of cell cycle check points and increased expression of p21. Moreover, by increasing Bax/Bcl-2 ratio outburst of cytochrome $\mathrm{C}$, activating AMPK, and by decreasing autophagy flux and survivin expression, ginger derivatives provoke cancer cell death. They participate in the alteration of redox homeostasis, which stops cancer cell proliferation. By blocking activation of p38 MAP kinase (p38 MAPK) and NF-kB, ginger derivatives inhibit COX-2 expression and as a result block angiogenesis. Ginger extracts decrease $\beta$-catenin in the WNT signaling pathway, which leads to the inhibition of gene transcription, involved in EMT and CSCs, and, additionally, downregulate MRP1 and GST-protein expression, involved in multidrug resistance.

\section{Ginger Derivatives and Cell Cycle Arrest}

Cell cycle is critical to maintaining cell proliferation and tissue integrity; therefore, it is thoroughly controlled in defined checkpoints by specific proteins and kinases that include cyclins, cyclin-dependent kinases (CDKs), and CDK inhibitors (CKIs) [30]. Deregulation of cell cycle and/or its arrest are often responsible for cancer onset and progression [30]. Experimental studies demonstrated that some ginger derivates were able to modulate cell cycle progression as a part of their chemopreventive mechanism [40] (Figure 2) For example, in recent work regarding the treatment of breast cancer cells (MCF-7 and MDAMB-231) with 6-shogaol, the arrest of the cell cycle in G2/M phase was reported in both monolayer and cancer-stem cell-like spheroids, and in the last experimental setting, 6shogaol also interfered with the stem cell self-renewal pathway [13]. In another study, ginger extract arrested cell cycle at G0/G1 and G2/M phases in the HT 29 colon cancer cell line at a low concentration $(455 \mu \mathrm{g} / \mathrm{mL})$, whereas in the HCT116 colon cancer cell line, the same effect was reached at a higher concentration $(496 \mu \mathrm{g} / \mathrm{mL})$ due to the inhibitory effect on CDKs [41]. Furthermore, in the HT29 and HCT116 colon cancer cell lines, ginger extract treatment caused a significant reduction in cyclin D1 gene expression coupled with down-regulation of mTOR and Wnt/ $\beta$-catenin pathways and consequent cell cycle arrest in the G0/G1 phase [41,42]. In addition, it was reported that human colon cancer cells (HCT116) treated with R. stricta (CAERS) and crude flavonoid extracts from Z. officinale (CFEZO) acted synergistically in cycle progression by inhibiting cMyc and the Cdk4/cyclin complex while upregulating p21 expression, a transcriptional target of p53 [43]. Saha and co-workers observed that cancer prostate cell lines (human PC3; DU145; LNCaP 
and murine HMVP2) treated with 6-shogaol, showed decreased levels of several signal transducer and activator of transcription 3 (STAT3) and NF- $\mathrm{kB}$-regulated target genes including cyclin D1 [14]. In addition, zerumbone (a sesquiterpene derived from the ginger plant Zingiber zerumbet) caused the arrest of cell cycle in the G1 phase in human prostate cancer cell line (DU-145) culture [14]. Furthermore, zerumbone caused a cell cycle arrest at G2/M (in a dose-dependent manner) by inhibiting PI3K/AKT/mTOR and STAT3 in hepatocellular carcinoma (human HepG2, Hep3B, Sk-Hep-1, SNU-182, SNU-449, Huh-7, and MHCC-LM3 cell lines, and murine Hepa1 cell line) [25]. The same compound impeded shunting of glucose-6-phosphate through the pentose phosphate pathway, thereby forcing tumor cells to undergo a cell cycle arrest. In human gastric adenocarcinoma (AGS), the 6-gingerol treatment showed a notable increase in the percentage of cells in the G2/M phase, accompanied by a resultant decrease of cells in the SubG0 phase [8].

Another study showed that zerumbone (ZER) administration significantly retarded the growth of orthotopic MDA-MB-231 xenografts in severe combined immune-deficient (SCID) mice [44]. The antitumor effect of ZER in vivo was accompanied by reduced cell proliferation as evidenced by Ki-67 (proliferation marker) expression and increased apoptosis. Additionally, ZER administration was well-tolerated by the mice and did not cause weight loss or any other side effects.

Based on the above-mentioned observations, it seems evident that ginger derivatives interfere with the proliferation and cell cycle of cancer cells by arresting cell cycle in G0/G1 or G2/M phases, by significantly reducing the cyclin D1 gene expression, by upregulating p21 expression, and by inhibiting PI3K/AKT/mTOR and STAT3.

\section{Ginger and Cellular Death}

Apoptosis, or programmed cell death, evolved as a rapid and irreversible process to efficiently eliminate dysfunctional cells [31]. Apoptosis is usually executed in two ways: Mitochondria-mediated intrinsic pathway and death receptor-mediated extrinsic route. In this process are involved cysteine-aspartate proteases (caspases) and the Bcl-2 family proteins (e.g., Bax, Bcl-2) [29,32]. Moreover, it is well known that in pathological conditions such as cancer, alterations/mutations in the p53 gene are one of the main causes of apoptosis changes [33]. As matter of fact, studies effected by Pashaei-Asl et al. showed that the treatment of ovarian cancer cell line SKOV-3 with ginger extract for $48 \mathrm{~h}$ caused the decrease of Bcl-2 gene expression, and the subsequent p53-induced apoptosis [45]. In another study, depolarization of the mitochondrial membrane and its potential subsequent deterioration $(\triangle \Psi \mathrm{m})$ were observed after 6-gingerol administration within the human gastric adenocarcinoma cell line (AGS) [8]. Interestingly, disruption of the mitochondrial permeability through the transition pore with decrease in $\Delta \Psi \mathrm{m}$ is one of the pivotal events in cell response to apoptotic stimuli [34]. Mitochondria-mediated apoptosis in 6-gingeroltreated AGS cells was followed by cytochrome c release, elevation in the Bax/Bcl-2 ratio, and activation of caspases-3 and -9 [8]. Aqueous extract of ginger (GAE) induced cellular apoptosis and disrupted cellular interphase microtubules also within human non-small lung epithelium cancer (NSCLC) A549 cell lines, by increasing the Bax/Bcl-2 ratio and activating the mitochondrial death cascade [46]. In addition, 6-shogaol induced apoptosis in hepatocarcinoma cell lines (Hep-2) by loss of cell viability, enhanced ROS production, lipid peroxidation resulted in altered mitochondrial membrane potential, and increased DNA damage [15]. In particular, the prooxidant role of 6-shogaol seemed to inhibit Bcl-2 expression accompanied by an up-regulation of Bax, cytochrome c, released by altered mitochondria, and caspases- 3 and -9 activation [15]. Similarly, $\beta$-Elemene, another extract from the ginger plant, triggered apoptosis in NSCLC through the cytochromec mitochondrial release, mediating the intrinsic apoptotic pathway [47]. Furthermore, torch ginger (Etlingera elatior, EE) induced caspase-independent cell death in mouse B16 melanoma cells through the inhibition of the ERK1/2, p38, and Akt signaling pathway [37]. In fact, it is well-known that the PI3K/Akt, ERK1/2, and p38 MAPK signaling pathways are crucial in the context of DNA-damaging drug-induced apoptosis [38]. Terpenoids present 
in the Steam Distilled Extract of Ginger (SDGE) induced apoptosis in endometrial cancer cells (ECC-1 and Ishikawa cell lines) at IC50 of $1.25 \mu \mathrm{g} / \mathrm{mL}$ by increasing the expression of p53 and Bax and simultaneously decreasing the expression of Bcl-2 by $90 \%$ [48].

Survivin is a member of the inhibitor of apoptosis (IAP) family and results in being up-regulated in different human cancers [35]. Interestingly, over-expression of this protein is associated with inhibition of apoptosis, resistance to chemotherapy, and a higher aggressiveness of tumors [49]. In this context, recent study showed that 6-shogaol, at $20 \mu \mathrm{M}$ and $40 \mu \mathrm{M}$, provoked downregulation of survivin in head and neck squamous cell carcinoma (HNSCC) cell lines and consequently a significant increase in apoptotic death [16].

A very important fact is that there are some results of in vivo experiments confirming the positive role of ginger derivatives in apoptosis induction within cancer. In this setting, oral squamous cell carcinoma induced by painting with $0.5 \%$ 7,12-dimethylbenz[a]anthraceneinduced (DMBA-induced) in hamster buccal pouch (HBP) (male golden Syrian hamsters) evidenced over-expression of the mutant form of p53 and Bcl-2 coupled with decreased expression of wild type p53 and Bax [17,50]. Oral treatment with 6-shogaol (at $20 \mathrm{mg} / \mathrm{kg}$ of body weight) showed significantly decreased tumor volume and tumor burden, restored wild-type p53 function, and activation of apoptotic stimuli [17].

Methanolic extract of Zingiber officinale rhizome (ZOME) induced morphological changes such as cell shrinkage and nuclear condensation demonstrating apoptotic properties of ZOME within cervical cancer HeLa and breast cancer MDA-MB-231 cell lines 1. Moreover, apoptosis of these cancer cell lines was gradually raised with an increasing order of concentration of extract, which revealed dose-dependent apoptosis [51].

Autophagy is a self-destructive process important for balancing sources of energy in the embryo development and as a response to several triggers of cellular stress (e.g., deprivation of growth factors/nutrients, inhibition of proteasome, inhibition of receptor tyrosine kinases/Akt/mammalian target of rapamycin (mTOR) signaling, and unbalance of ROS homeostasis) and is characterized by a cascade of events including degradation of cytoplasmic proteins or entire organelles $[36,52,53]$. Interestingly, the correlation between autophagy and cancer is controversial; in this context, it seems that autophagy could act as a tumor suppressor, provoking a programmed cell death of type II [22] and/or as tumor activator, directly affecting the cell-matrix focal adhesions (FAs), essential for efficient migration and invasion of cells [39].

Interestingly, co-treatment with gingerol and TRAIL of TRAIL-resistant A549 adenocarcinoma cells increased the LC3-II and p62 levels, that attested the inhibition of autophagy [54]. The gingerol treatment strongly enhanced apoptosis in TRAIL-resistant A549 cells, which was confirmed by the intracellular apoptosis indicator cleaved caspase-3. The results of this study suggested that gingerol sensitized TRAIL-induced apoptosis in A549 lung adenocarcinoma cells by inhibiting autophagy flux.

The semi-synthetic analogue SSi6, generated after chemical modification of the 6gingerol molecule, using the acetone-2,4- dinitrophenylhydrazone (2,4-DNPH) reagent, enhanced selective cytotoxic effects on MDA-MB-231 (Triple negative breast cancer, (TNBC)) cells [55]. Remarkably, unlike the original 6-gingerol molecule, SSi6 enabled autophagy followed by caspase-independent apoptosis in tumor cells. A time-dependent association between SSi6-induced oxidative stress, autophagy, and apoptosis was reported. Initial SSi6-induced ROS accumulation ( $1 \mathrm{~h}$ ) led to autophagy activation (2-6 h), which was followed by caspase-independent apoptosis $(14 \mathrm{~h})$ in TNBC cells. Additionally, the data showed that SSi6 induction of ROS accumulation played a key role in the promotion of autophagy and apoptosis [55]. Another experiment showed that breast cancer cells MCF-7 and MDA-MB-231 after 6-shogaol treatment underwent cell death, exploiting the autophagy route proved by cytoplasmic vacuole formation as well as the recruitment and cleavage of the microtubule-associated protein LC3 [13].

Another recent study showed that 6-Gingerol treatment in the human lung cancer cell line (A549) and in A549 tumor xenografts could increase the number of autophagosomes, ROS, and iron concentration, decrease the survival and proliferation rate of A549 cells, and 
significantly decrease tumor volume and weight [56]. Interestingly, 6-Gingerol treatment significantly suppressed USP14 expression, indicating that 6-Gingerol promoted autophagy effected by inhibition of USP14-Beclin 1. Remarkably, daily oral feeding of $100 \mathrm{mg} / \mathrm{kg}$ body weight of ginger extract (GE) inhibited growth and progression of PC-3 (prostate cancer) xenografts by approximately $56 \%$ in nude mice, as shown by measurements of tumor volume [57]. Tumor tissue from GE-treated mice showed reduced proliferation index and widespread apoptosis, as determined by immunoblotting and immunohistochemical methods, compared with controls.

Also, recent research demonstrated that the human pancreatic cancer (Panc-1) cell line treated with the extract of Syussai ginger (SSHE) revealed several features that were not observed in classical-type autophagy, including nuclear shrinkage, focal membrane rupture, electron dense mitochondria, empty vacuoles, and focal perinuclear swelling [58]. It appeared that these morphological features coincided well with the recently discovered form of cell death, "autosis", which is a $\mathrm{Na}^{+}$and $\mathrm{K}^{+}$-ATPase-regulated form of cell death [23]. SSHE markedly increased the LC3-II/LC3-I ratio, decreased SQSTM1/p62 protein, and enhanced vacuolization of the cytoplasm in Panc-1 cells. So, SSHE inhibited cell proliferation and subsequently induced the autotic death of pancreatic cancer Panc1 cells.

To sum up, the chemopreventive effect of ginger derivatives may be expressed by its ability to enhance some types of cellular death in cancer, like apoptosis, autophagy, and autosis by elevating Bax/Bcl-2 ratio, releasing cytochrome c, activating caspases-3 and -9 , and downregulating the survivin.

\section{Ginger, Its Constituents, and ROS Balance}

Reactive oxygen species (ROS) are a group of highly reactive molecules generated through a variety of sources (mitochondria, NADPH oxidases (Nox), xanthine oxidase (XO), and uncoupled endothelial nitric oxide synthase (eNOS), lipoxygenase, cyclooxygenase, and CYP-P450s enzymes) [59-61]. Elevated ROS rates have been detected in almost all cancers, where they promote many aspects of tumor development and progression. However, tumor cells also express increased levels of antioxidant proteins to detox from ROS, suggesting that a delicate balance of intracellular ROS levels is required for cancer cell function [62].

A challenge for novel therapeutic strategies will be to direct the ROS signaling towards ROS-induced apoptotic route. In this scenario, recent studies showed that ZOME scavenged the ROS actions, in a dose-dependent manner, both in human cervical cancer (HeLa) cells and in breast cancer (MDA-MB-231) cells [51]. Another study reported that after treatment of AGS cells with 6-gingerol, an increase in the level of reactive ROS led to a decrease in mitochondrial membrane potential and consequent induction of apoptosis [8]. Also, the incubation of DU-145 prostate carcinoma cells with zerumbone led to a reduction of cell viability, in a dose- and time-dependent manner, by increasing the ROS production [63]. Additionally, Akimoto and co-workers demonstrated that the extract of Syussai ginger (SSHE) had a strong inhibitory effect on cell growth as well as pro-apoptotic activity in pancreatic cancer in vitro [58]. In particular, the authors showed that ROS production was suppressed in SSHE-treated Panc-1 cells at early stages that might be due to the antioxidant properties of the ginger extract [64]. However, prolonged treatment of cells with SSHE caused a marked increase in ROS production, which induced autotic cell death. The extract was also effective under hypoxic conditions, which inevitably develop in all solid tumors to varying degrees and influence the resistance of tumor cells to radiotherapy and conventional chemotherapy [64]. Recently, Kathiresanet et al. discovered that 6-shogaol ( $20 \mathrm{mg} / \mathrm{kg}$ body weight) had a potent anticancer activity against DMBA-induced oral carcinogenesis in the HBP model by restoring antioxidant levels, thereby preventing lipid peroxidation. In addition, 6-shogaol was also able to inhibit phase I enzymes (Cyt-p450 and Cyt-b5) and increase phase II enzymes (GST, GR, and GSH) that enhanced the detoxification, thereby preventing the carcinogenesis [17]. 
Another interesting clinical study had the principal objective to examine the antioxidant activity of ginger extract orally administered as a daily supplement in newly diagnosed solid tumor patients receiving moderate-to-high emetogenic potential chemotherapy [65]. All participants were women, of whom 39 patients (91\%) were diagnosed with breast cancer who received anthracycline-based regimen, 24 patients $(56 \%)$ were diagnosed with stage II, and 13 patients (30\%) diagnosed with stage III. In all, $90 \%$ of patients had a good performance status $(E C O G=0)$. A daily supplement of ginger extract, started 3 days prior to chemotherapy, showed significantly elevated antioxidant activity and reduced oxidative marker levels in patients who receive moderate-to-high emetogenic potential chemotherapy compared to a placebo [65]. In subsequent cycles of chemotherapy, patients seemed to have significantly elevated oxidative defense status based on their higher blood levels of $\mathrm{Cu}-\mathrm{Zn}$ superoxide dismutase (CuZn-SOD), catalase (CAT), glutathione (GSH/GSSG), and GPx couplet with significantly reduced levels of malondialdehyde (MDA) and $\mathrm{NO}_{2}-/ \mathrm{NO}_{3}$ - after continuously receiving ginger extract. This effect was not observed in patients who received placebos. Furthermore, patients taking ginger extract continuously were inclined to increase antioxidant enzyme blood levels and decrease oxidative stress blood level [65].

In summary, ginger derivatives could play an important role in maintaining redox homeostasis: In some cases, by decreasing the quantity of ROS-induced tumor-promoting events, and in other cases, in contrast, by increasing oxidative stress and provoking cell death.

\section{Ginger and Angiogenesis}

Angiogenesis, the formation of new blood vessels from pre-existing endothelium, depends on complex cellular activities, such as extracellular matrix degradation, proliferation and migration of endothelial cells, and morphological differentiation of endothelial cells to form tubes. Thus, this phenomenon is tightly controlled by positive factors such as vascular endothelial growth factor (VEGF) and negative regulators including endostatin, thrombospondin, etc., [66,67]. Neovascularization is fundamental in a variety of physiological processes such as embryonic development and pregnancy [68]. On the other hand, angiogenesis is a crucial event for tumor progression and metastatic cascade, therefore many cancer therapies are directed against the tumor-associated vasculature [69-71]. Recent observation showed that a series of natural compounds, including ginger extracts, were proposed as antiangiogenic/angiopreventive substances both in in vitro and in vivo [20,26]. In this contest, it was demonstrated that 6-gingerol was able to inhibit the proliferation and tube formation of human umbilical vein endothelial cells (HUVECs) in response to VEGF or bFGF [9]. Also, 6-gingerol strongly inhibited sprouting of endothelial cells in the rat aorta model and angiogenesis in the mouse cornea in response to VEGF; while in the mouse model of melanoma, i.p. administration of the above-mentioned ginger extract reduced the number of lung metastasis, with the preservation of apparently healthy behavior [9]. Kim and their collaborators showed that in phorbol ester-stimulated mouse skin, 6-gingerol was capable of inhibiting tumor promoter-induced activation of AP-1 and COX-2 expression by blocking the activation of p38 MAP kinase (p38 MAPK) and NF-kB [72]. Since p38 MAPK, $\mathrm{NF}-\mathrm{kB}$, and COX-2 are involved in angiogenesis, the anti-angiogenic activity of 6-gingerol might be due to blocking their activation.

Moreover, the use of CAM assay showed that ginger extracts were capable to reduce neovascularization as well as blood vessel diameter in a dose-dependent manner [73]. The importance of 6-gingerol in angioprevention and cancer treatment was also supported by further experimental evidence that demonstrated that the ginger extract was a potent inhibitor of endothelial cell proliferation as tube-like formation in vitro and in vivo, directly inhibiting the growth of rat YYT colon cancer cells or mouse MS1 endothelial cells in response to the growth factors derived from another colon cancer cell line (mouse CT26) [74]. Interestingly, there is an inverse dose-dependent relationship between proliferation and concentration of the ginger extract used [74]. 
NF- $\mathrm{KB}$, as well as IL-8, plays an important role in tumorigenesis, given its ability to control the expression and function of numerous genes involved in cell proliferation, sustained angiogenesis, and evasion from apoptosis. Different tumor types, including ovarian cancer, have been shown to express high constitutive NF- $\kappa B$ activity [75]. It was shown that 6-gingerol treatment of cultured ovarian cancer cells induced serious growth suppression by inhibiting NF-kB activation and decreasing the VEGF and IL-8 secretion [10].

In summary, ginger derivatives seem to be potent anti-angiogenic substances that point to a possible role in preventing cancer from becoming malignant, presumably by selective inhibition of neovessel formation in tumor sites.

\section{Cancer Stem Cells, Epithelial-Mesenchymal Transition and Ginger}

In many tumors, a subpopulation of cells named cancer stem cells (CSCs) is involved in dissemination through their stemness properties. In fact, CSCs play a critical role in metastatic potential, resistance to chemotherapies, as well as the relapse of malignancies [76-79]. These cells are frequently identified in various tumors, including brain, pancreas, liver, ovary, colon, lung, skin, and prostate cancers $[77,80,81]$. Together with CSCs, the epithelial-mesenchymal transition (EMT) is responsible for the metastatic propensity of cancer; in fact, it is reported that EMT cells show stem cell-like facets [82,83]. The Wnt/ $\beta$-catenin signaling pathway is considered to be a critical inducer of the EMT process and is important in maintaining cancer stem cell properties [84], and $\beta$-catenin is the main mediator for the Wnt signaling from the cytoplasm through the nucleus $[27,85,86]$. Different studies show that defective functions in the Wnt/ $\beta$-catenin pathway are the key oncogene stimulus in $90 \%$ of patients affected by colon cancer and, coincidently, this pathway has a principal role in CSCs maintenance in CRC patients [76,87].

MicroRNAs (miRs) are endogenously small, noncoding RNAs that can post-transcriptionally regulate gene expression and seem to play an important role in maintaining normal cellular functions [88]. Studies have shown that the miR-200 family plays a significant role in the inhibition of the proliferation and metastases potential of CSCs and EMT phenomenon by suppressing Wnt/catenin signaling [89]. One recent study showed that zerumbone could reverse EMT to the mesenchymal-epithelial transition (MET) through the upregulation of miR-200c by decreasing $\beta$-catenin expression in CRC HCT-116 and SW-48 cell lines and by inhibiting the transcription of genes involved in EMT and CSCs [90]. As a result, CRC HCT-116 and SW-48 cell lines showed reduced cell viability after zerumbone treatment.

Another study demonstrated that ZD 2-1, a mixture of ZD 2, novel zingerone derivative, and zingerone, significantly inhibited the TGF- $\beta 1$ induced an increase in migration and invasion in SNU182 hepatocellular carcinoma cells when the concentration of ZD 2-1 reached $40 \mu \mathrm{M}$ [18]. In particular, ZD 2-1 inhibited nuclear translocation of NF-kB and activation of p42/44 MAPK/AP1 signaling pathways in the TGF- $\beta 1$ induced EMT, probably by inhibiting activation of MMP-2/9 and p42/44 MAPK [87].

In another experiment, 6-shogaol was found to interfere with the Notch pathway, which is known to be actively involved in the self-renewal of CSCs. The treatment of MCF-7 and MDA-MB-231 breast cancer lines, both in monolayer and 3D spheroids configuration, with $25 \mu \mathrm{M}$ of 6-shogaol, reduced the cleavage of Notch1 in a time-dependent manner, and consequently, decreased the Notch targets (Hes1 and Cyclin D1), in this way interfering with the stem cell self-renewal pathway [13].

Additionally, the anti-tumor effects of [10]-gingerol in vivo was validated by using metastatic 4T1Br4 tumor-bearing mice [91]. Control mice over the subsequent 14 days of treatment showed weight loss, indicative of cachexia typically observed in mice with a high tumor burden. In contrast, mice from the [10]-gingerol $(10 \mathrm{mg} / \mathrm{kg})$ group gained some weight. The results indicated a significantly lower incidence of mice with brain lesions in the [10]-gingerol-treated group (1/13) compared to controls (7/13) [91]. Moreover, [10]gingerol reduced spontaneous lung and bone metastatic burden. In addition, [10]-gingerol 
was well-tolerated in vivo, induced a marked increase in caspase-3 activation, and inhibited orthotopic tumor growth in a syngeneic mouse model of spontaneous breast cancer metastasis. Importantly, by using both spontaneous and experimental metastasis assays, it was evidenced that [10]-gingerol significantly inhibited metastasis of multiple organs including lung, bone, and brain.

\section{Ginger and Multidrug Resistance}

Multidrug resistance (MDR) mechanisms are associated with increased expression of the P-glycoprotein (Pgp) or increased cellular metabolism of drug detoxifying proteins, such as glutathione-S-transferase (GST), that are correlated with increased resistance to apoptosis [24,92]. Additionally, multidrug resistance-associated protein 1 (MRP1), involved in the transport of many antitumor agents, is overexpressed in many chemoresistant cancer types including gastric cancer, neuroblastoma, and prostate cancer $[93,94]$.

Recent research found that GST and MRP1 protein expression in the docetaxel-resistant human prostate (PC3R) cancer cell line was higher than in the docetaxel-sensitive human prostate (PC3) cancer cell line [95]. The results showed that 6-gingerol, 10-gingerol, 6shogaol, and 10-shogaol inhibited the proliferation of PC3R cells through the downregulation of MRP1 and GST-protein expression [95]. Another study showed that a combined therapy of 6-gingerol with doxorubicin (doxo) could enhance the efficacy of doxo-based regiments in the treatment of Pgp-mediated MDR tumor with no severe side effects [12]. 6-gingerol in combination with doxo produced a significant increase of doxo accumulation (up to $44 \%$ ) with the concentration of ginger at 10 and $20 \mu \mathrm{M}$ in combination with doxo 2, 4, and $8 \mu \mathrm{M}$ within the doxo-resistant human uterus sarcoma cell line MES-SA/Dx5. Additionally, the increase in GSH production was significant (up to 13\%) at a higher (20 $\mu \mathrm{M})$ 6-gingerol concentration [12]. So, on one hand, 6-gingerol could act as chemosensitizer inhibiting Pgp activity and, on the other hand, at high concentrations, it could have an anti-oxidative capacity that could be useful to protect MDR-negative normal cells against the damage caused by the generation of free radicals during anticancer treatment while its extrusion from resistant cells via Pgp could reduce the protective effects of cells increasing doxo sensitivity. Combined treatment of ginger oil with Methotrexate (MTX) increased the cytotoxic effect of MTX by 1.54-fold for the CCRF-CEM, T-cell Acute Lymphoblastic Leukemia (T-ALL) malignant cell line and 2.3-fold for Nalm-6 (B-ALL) cells, while the cytotoxic activity of this herbal extract in normal mononuclear cells was negligible [11]. Additionally, 11 out of 12 patient samples showed 1.2-16.5\% increased apoptosis compared with the untreated samples. It was also shown that the more resistant cells were to the chemotherapy drug, the more sensitive they were to the medicinal herb. These data introduced ginger as a promising candidate for improved combination therapies in ALL, especially for those patients who show resistance to chemotherapy [11].

\section{Ginger Enhanced Bioavailability and Combined Treatment}

Low bioavailability alongside the poor solubility of ginger derivatives hinders their clinical application, probably due to poor absorption, hydrophobicity, extreme instability, and rapid metabolism, with concomitant elimination [96,97]. Recently, nanotechnologies (polymer nanoparticles or micelles, liposomes, inorganic nanoparticles, and nanoemulsions) have shown a huge advantage in enhancing bioavailability of these compounds as well as their oral absorption, reducing medicinal herb doses and toxicity, thereby improving the target ability and therapeutic effects [98,99]. Comparatively, self-assembled micelles could provide several advantages to drug delivery systems because of their high drug loading capacity, low dose of formulation required, and long circulation time [100,101]. In the recent study, the polyethylene glycol (PEG) derivative of linoleic acid (mPEG2K-LA) was first employed as a material for forming micelles to encapsulate 6-shogaol and enhance its solubility [102]. The formulated 6-shogaol loaded micelles (SMs) significantly slowed the drug release in stimulated media of the gastrointestinal tract and increased the sensitivity of tumor cells to the prototype drug. A high drug encapsulation of $80 \%$ was achieved under 
a drug loading capacity of $7 \%$, which greatly enhanced the 6-shogaol delivery efficiency versus general oral delivery systems. Therefore, SMs show a slower release rate than the free 6-shogaol [102]. More importantly, the in vitro cytotoxic effect of SMs in HepG2 cells is significantly higher than free 6-shogaol [102]. In addition, SMs showed enhanced oral bioavailability and liver and brain distribution compared to free 6-shogaol. The in vivo liver protection study in mice also demonstrated that SMs markedly reduced the activities of serum AST, ALT, and liver MDA levels, while they remarkably increased the antioxidant activities (GSH-Px, T-SOD). Therefore, the novel SMs are expected to serve as a promising carrier for 6-shogaol to enhance its cancer treatment and hepatoprotection [102].

Because radiotherapy is one of the main treatment options in head and neck cancer, 6-shogaol was combined with irradiation to evaluate a possible radiosensitizing effect [16]. The results of this study showed that 6-shogaol enhanced the effect of irradiation on SCC25, CAL27, two squamous cell carcinoma cell lines of the tongue and FaDu, and a squamous cell carcinoma cell line of the pharynx in vitro. Cell viability assays showed that irradiation in combination with 6-shogaol lead to a stronger growth inhibition than each treatment method alone. Experiments demonstrated a synergistic effect of 6-shogaol and irradiation, therefore a radiosensitizing capability of 6-shogaol can be supposed [16]. A recent study described a nanovector made from ginger-derived lipids that can serve as a delivery platform for the therapeutic agent doxorubicin (doxo) to treat colon cancer [28]. The nanoparticles from ginger were created and their lipids were reassembled into gingerderived nanovectors (GDNVs). A subsequent characterization showed that GDNVs are efficiently taken up by colon cancer cells. Modified GDNVs conjugated with the targeting ligand folic acid-mediated targeted delivery of doxo to Colon-26 tumors in a xenograft tumor model in vivo and enhanced the chemotherapeutic inhibition of tumor growth compared with free drug [28]. Such delivery vehicles have enhanced the permeability and retention effect that allowed drugs to reach tumors more passively through leaky vasculatures surrounding the mass. The result of this study demonstrated that GDNVs loaded with doxo successfully inhibited tumor growth in a Colon-26 xenograft tumor model [28].

Additionally, the studies reported the effects of combined treatment (ginger and gelam honey), which downregulate the gene expressions of Akt, mTOR, Raptor, Rictor, $\beta$-catenin, Gsk3 $\beta$, Tcf4, and cyclin D1 while cytochrome $C$ and caspase 3 genes were shown to be upregulated in HT29 colon cancer cells [103]. Furthermore, an extract mixture of turmeric, ginger, and garlic induced apoptosis in MCF-7 and ZR-75 breast cancer cell lines [104]. A combined treatment with NE mix-tamoxifen caused the extension of apoptosis indicating a potential role of the NE mix in sensitizing the ER-positive breast cancer cells towards tamoxifen. Moreover, a combined treatment with NE mix-tamoxifen altered the expression of apoptotic markers (p53 and Caspase 9) leading to apoptosis in breast cancer cell lines.

So, nanotechnologies and combined treatment seem to increase the efficiency of ginger derivatives therapeutic effects by increasing their bioavailability.

\section{Conclusions and Future Perspectives}

Nowadays, available drugs for treating cancer are often toxic, expensive, and little effective. Ginger derivatives possess high potential chemopreventive properties such as cell cycle arrest, increased cellular death (apoptosis, autophagy and autosis), as well as redox homeostasis unbalance. Furthermore, they inhibit angiogenesis, CSCs formation, and the EMT process. Therefore, this natural compound directly and indirectly influences tumor cell survival and inhibits invasion and metastasis processes, without significant toxic effects on normal cells $[18,26]$. Additionally, ginger enhances the therapeutic efficacy of the currently available anti-cancer drugs and represents a good adjuvant to certain phytochemical compounds including turmeric, garlic, and gelam honey [103,104]. A very important moment in ginger derivatives' chemopreventive properties is that they do not cause side effects, but on the contrary, they ease the side effects provoked by other cancer treatments, like radio- and chemotherapy, giving ginger a considerable advantage in being considered 
a chemopreventive natural compound $[105,106]$. However, most of the known activities of ginger components have been studied only in in vitro and in vivo studies, except for a few clinical studies in human subjects. Therefore, more substantial and well-controlled clinical human studies are needed to illustrate its efficacy as an anticancer agent, since it is a safe and encouraging alternative. The recent development of nanotechnologies (polymer nanoparticles or micelles, liposomes, inorganic nanoparticles, and nano-emulsions) provides a chance to improve oral absorption, bioavailability of ginger, while also improving the target ability and its therapeutic effects [28,102]. In summary, ginger derivatives have various health effects and therapeutic properties; nevertheless, their biological applications are limited due to their hydrophobic nature. The low aqueous solubility of this compound seems to be the major obstacle for its lab-to-clinic development as a drug; therefore, it appears to be necessary to use advanced extraction methods to improve its bioavailability.

Author Contributions: M.Z. wrote and prepared the manuscript; D.M. wrote and supervised the manuscript. All authors have read and agreed to the published version of the manuscript.

Funding: This research received no external funding.

Conflicts of Interest: None of the authors have a conflict of interest.

$\begin{array}{ll}\text { Abbreviations } & \\ \text { ALT } & \text { alanine aminotransferase } \\ \text { AP-1 } & \text { activator protein 1 } \\ \text { AST } & \text { aspartate aminotransferase } \\ \text { ATPase } & \text { adenosine triphosphatase } \\ \text { B-ALL } & \text { B-cell Acute Lymphoblastic Leukemia } \\ \text { Bcl-2 } & \text { B-cell lymphoma 2 } \\ \text { CAM } & \text { chorioallantoic membrane } \\ \text { Caspases } & \text { cysteine-aspartate proteases } \\ \text { CAT } & \text { catalase } \\ \text { CDK } & \text { cyclin-dependent kinases } \\ \text { CFEZO } & \text { crude flavonoid extracts from Z. officinale } \\ \text { CKI } & \text { cyclin-dependent kinases inhibitor } \\ \text { COX-2 } & \text { cyclooxygenase-2 } \\ \text { CRC } & \text { colorectal carcinoma } \\ \text { CSCs } & \text { cancer stem cells } \\ \text { CuZn-SOD Cu-Zn } & \text { superoxide dismutase } \\ \text { CYP-P450 } & \text { cytochrome P450 } \\ \text { DMBA } & \text { 0.5\% 7,12-dimethylbenz[a]anthracene } \\ \text { DNA } & \text { deoxyribonucleic acid } \\ \text { DNPH } & \text { dinitrophenylhydrazone } \\ \text { ECOG } & \text { Eastern Cooperative Oncology Group } \\ \text { EE } & \text { Etlingera elatior } \\ \text { EMT } & \text { epithelial-mesenchymal transition } \\ \text { eNO } & \text { endothelial nitric oxide synthase } \\ \text { ERK } & \text { Extracellular signal-regulated kinase } \\ \text { FAs } & \text { focal adhesions } \\ \text { GAE } & \text { aqueous extract of ginger } \\ \text { GDNVs } & \text { ginger-derived nanovectors } \\ \text { GR } & \text { glutathione reductase } \\ \text { GSH } & \text { Glutathione } \\ \text { GST } & \text { glutathione-S-transferase } \\ \text { HBP } & \text { hamster buccal pouch } \\ \text { HNSCC } & \\ \text { HUVECs } & \text { head and neck squamous cell carcinoma } \\ \text { IL-8 } & \end{array}$




\begin{tabular}{|c|c|}
\hline LC3-II & light chain3-II \\
\hline MAPK & Mitogen-Activated Protein Kinase \\
\hline MDA & malondialdehyde \\
\hline MDR & multidrug resistance \\
\hline MET & esenchymal-epithelial transition \\
\hline miRs & microRNA \\
\hline MMP & Matrix metalloproteinase \\
\hline MRP1 & multidrug resistance-associated protein 1 \\
\hline mTOR & the mechanistic target of rapamycin \\
\hline MTX & methotrexate \\
\hline NADPH & Nicotinamide adenine dinucleotide phosphate \\
\hline NF- $k \mathrm{~B}$ & nuclear factor kappa-light-chain-enhancer of activated B cells \\
\hline Nox & NADPH oxidases \\
\hline NSCLC & non-small-cell lung cancer \\
\hline PEG & Polyethylene Glycol \\
\hline Pgp & P-glycoprotein \\
\hline PI3K & phosphatidylinositol-3-kinase \\
\hline RNA & ribonucleic acid \\
\hline ROS & reactive oxygen species \\
\hline SCID & severe combined immune deficient \\
\hline SDGE & Steam Distilled Extract of Ginger \\
\hline SMs & 6-shogaol loaded micelles \\
\hline SSHE & extract of Syussai ginger \\
\hline STAT3 & signal transducer and activator of transcription 3 \\
\hline T-ALL & T-cell Acute Lymphoblastic Leukemia \\
\hline TNBC & triple negative breast cancer \\
\hline TNF & tumor necrosis factor \\
\hline TRAIL & TNF-related apoptosis-inducing ligand \\
\hline USP14 & ubiquitin-specific peptidase 14 \\
\hline VEGF & vascular endothelial growth factor \\
\hline $\mathrm{XO}$ & xanthine oxidase \\
\hline ZOME & Methanolic extract of Zingiber officinale rhizome \\
\hline
\end{tabular}

\section{References}

1. Wang, H.; Naghavi, M.; Allen, C.; Barber, R.M.; Bhutta, Z.A.; Carter, A.; Casey, D.C.; Charlson, F.J.; Chen, A.Z.; Coates, M.M.; et al Causes of Death, Global, regional, and national life expectancy, all-cause mortality, and cause-specific mortality for 249 causes of death, 1980-2015: A systematic analysis for the Global Burden of Disease Study 2015. Lancet 2016, 388, 1459-1544. [CrossRef]

2. Scott, A.M.; Wolchok, J.D.; Old, L.J. Antibody therapy of cancer. Nat. Rev. Cancer 2012, 12, 278-287. [CrossRef] [PubMed]

3. Liang, X.-J.; Chen, C.; Zhao, Y.; Wang, P.C. Circumventing Tumor Resistance to Chemotherapy by Nanotechnology. Methods Mol. Biol. 2009, 596, 467-488. [CrossRef]

4. Seca, A.M.L.; Pinto, D.C.G.A. Plant Secondary Metabolites as Anticancer Agents: Successes in Clinical Trials and Therapeutic Application. Int. J. Mol. Sci. 2018, 19, 263. [CrossRef] [PubMed]

5. Aggarwal, B.B.; Shishodia, S. Molecular targets of dietary agents for prevention and therapy of cancer. Biochem. Pharmacol. 2006, 71, 1397-1421. [CrossRef] [PubMed]

6. Kim, Y.-S.; Hong, C.S.; Lee, S.W.; Nam, J.H.; Kim, B.J. Effects of ginger and its pungent constituents on transient receptor potential channels. Int. J. Mol. Med. 2016, 38, 1905-1914. [CrossRef]

7. Wei, C.-K.; Tsai, Y.-H.; Korinek, M.; Hung, P.-H.; El-Shazly, M.; Cheng, Y.-B.; Wu, Y.-C.; Hsieh, T.-J.; Chang, F.-R. 6-Paradol and 6-Shogaol, the Pungent Compounds of Ginger, Promote Glucose Utilization in Adipocytes and Myotubes, and 6-Paradol Reduces Blood Glucose in High-Fat Diet-Fed Mice. Int. J. Mol. Sci. 2017, 18, 168. [CrossRef]

8. Mansingh, D.P.; OJ, S.; Sali, V.K.; Vasanthi, H.R. [6]-Gingerol-induced cell cycle arrest, reactive oxygen species generation, and disruption of mitochondrial membrane potential are associated with apoptosis in human gastric cancer (AGS) cells. J. Biochem. Mol. Toxicol. 2018, 32, e22206. [CrossRef] [PubMed]

9. Kim, E.-C.; Min, J.-K.; Kim, T.-Y.; Lee, S.-J.; Yang, H.-O.; Han, S.; Kim, Y.-M.; Kwon, Y.-G. [6]-Gingerol, a pungent ingredient of ginger, inhibits angiogenesis in vitro and in vivo. Biochem. Biophys. Res. Commun. 2005, 335, 300-308. [CrossRef] [PubMed]

10. Rhode, J.; Fogoros, S.; Zick, S.; Wahl, H.; Griffith, K.A.; Huang, J.; Liu, J.R. Ginger inhibits cell growth and modulates angiogenic factors in ovarian cancer cells. BMC Complement. Altern. Med. 2007, 7, 44. [CrossRef]

11. Babasheikhali, S.R.; Rahgozar, S.; Mohammadi, M. Ginger extract has anti-leukemia and anti-drug resistant effects on malignant cells. J. Cancer Res. Clin. Oncol. 2019, 145, 1987-1998. [CrossRef] 
12. Angelini, A.; Conti, P.; Ciofani, G.; Cuccurullo, F.; Di Ilio, C. Modulation of multidrug resistance P-glycoprotein activity by antiemetic compounds in human doxorubicin-resistant sarcoma cells (MES-SA/Dx-5): Implications on cancer therapy. J. Boil. Regul. Homeost. Agents 2014, 27, 1029-1037.

13. Ray, A.; Vasudevan, S.; Sengupta, S. 6-Shogaol Inhibits Breast Cancer Cells and Stem Cell-Like Spheroids by Modulation of Notch Signaling Pathway and Induction of Autophagic Cell Death. PLoS ONE 2015, 10, e0137614. [CrossRef]

14. Saha, A.; Blando, J.; Silver, E.; Beltran, L.; Sessler, J.; DiGiovanni, J. 6-Shogaol from dried ginger inhibits growth of prostate cancer cells both in vitro and in vivo through inhibition of STAT3 and NF-kappaB signaling. Cancer Prev. Res. 2014, 7, 627-638. [CrossRef] [PubMed]

15. Annamalai, G.; Kathiresan, S.; Kannappan, N. [6]-Shogaol, a dietary phenolic compound, induces oxidative stress mediated mitochondrial dependant apoptosis through activation of proapoptotic factors in Hep-2 cells. Biomed. Pharmacother. 2016, 82, 226-236. [CrossRef]

16. Kotowski, U.; Kadletz, L.; Schneider, S.; Foki, E.; Schmid, R.; Seemann, R.; Thurnher, D.; Heiduschka, G. 6-shogaol induces apoptosis and enhances radiosensitivity in head and neck squamous cell carcinoma cell lines. Phytother. Res. 2018, 32, 340-347. [CrossRef] [PubMed]

17. Kathiresan, S.; Govindhan, A. [6]-Shogaol, a Novel Chemopreventor in 7,12-Dimethylbenz[a]anthracene-induced Hamster Buccal Pouch Carcinogenesis. Phytother. Res. 2016, 30, 646-653. [CrossRef]

18. Kim, Y.J.; Jeon, Y.; Kim, T.; Lim, W.C.; Ham, J.; Park, Y.N.; Kim, T.-J.; Ko, H. Combined treatment with zingerone and its novel derivative synergistically inhibits TGF- $\beta 1$ induced epithelial-mesenchymal transition, migration and invasion of human hepatocellular carcinoma cells. Bioorganic Med. Chem. Lett. 2017, 27, 1081-1088. [CrossRef] [PubMed]

19. Mashhadi, N.S.; Ghiasvand, R.; Askari, G.; Hariri, M.; Darvishi, L.; Mofid, M.R. Anti-Oxidative and Anti-Inflammatory Effects of Ginger in Health and Physical Activity: Review of Current Evidence. Int. J. Prev. Med. 2013, 4, S36-S42.

20. Habib, S.H.M.; Makpol, S.; Hamid, N.A.A.; Das, S.; Ngah, W.Z.W.; Yusof, Y.A.M. Ginger extract (Zingiber officinale) has anti-cancer and anti-inflammatory effects on ethionine-induced hepatoma rats. Clinics 2008, 63, 807-813. [CrossRef]

21. Lee, H.S.; Seo, E.Y.; Kang, N.E.; Kim, W.K. [6]-Gingerol inhibits metastasis of MDA-MB-231 human breast cancer cells. J. Nutr. Biochem. 2008, 19, 313-319. [CrossRef]

22. Choi, K.S. Autophagy and cancer. Exp. Mol. Med. 2012, 44, 109-120. [CrossRef]

23. Liu, Y.; Shoji-Kawata, S.; Sumpter, R.M.; Wei, Y.; Ginet, V.; Zhang, L.; Posner, B.; Tran, K.A.; Green, D.; Xavier, R.J.; et al. Autosis is a $\mathrm{Na}+, \mathrm{K}+-$ ATPase-regulated form of cell death triggered by autophagy-inducing peptides, starvation, and hypoxia-ischemia. Proc. Natl. Acad. Sci. USA 2013, 110, 20364-20371. [CrossRef] [PubMed]

24. Gameiro, M.; Silva, R.; Rocha-Pereira, C.; Carmo, H.; Carvalho, F.; Bastos, M.D.L.; Remião, F. Cellular Models and In Vitro Assays for the Screening of modulators of P-gp, MRP1 and BCRP. Molecules 2017, 22, 600. [CrossRef]

25. Wani, N.A.; Zhang, B.; Teng, K.-Y.; Barajas, J.M.; Motiwala, T.; Hu, P.; Yu, L.; Brüschweiler, R.; Ghoshal, K.; Jacob, S.T. Reprograming of Glucose Metabolism by Zerumbone Suppresses Hepatocarcinogenesis. Mol. Cancer Res. 2017, 16, 256-268. [CrossRef] [PubMed]

26. Lechner, J.F.; Stoner, G.D. Gingers and Their Purified Components as Cancer Chemopreventative Agents. Molecules 2019, $24,2859$. [CrossRef]

27. Zwezdaryk, K.J.; Combs, J.A.; Morris, C.A.; Sullivan, D.E. Regulation of Wnt/beta-catenin signaling by herpesviruses. World J. Virol. 2016, 5, 144-154. [CrossRef]

28. Zhang, M.; Xiao, B.; Wang, H.; Han, M.K.; Zhang, Z.; Viennois, E.; Xu, C.; Merlin, D. Edible Ginger-derived Nano-lipids Loaded with Doxorubicin as a Novel Drug-delivery Approach for Colon Cancer Therapy. Mol. Ther. 2016, 24, 1783-1796. [CrossRef] [PubMed]

29. Coultas, L.; Strasser, A. The role of the Bcl-2 protein family in cancer. Semin. Cancer Biol. 2003, 13, 115-123. [CrossRef]

30. Vermeulen, K.; Berneman, Z.N.; Van Bockstaele, D.R. Cell cycle and apoptosis. Cell Prolif. 2003, 36, 165-175. [CrossRef] [PubMed]

31. Elmore, S. Apoptosis: A review of programmed cell death. Toxicol. Pathol. 2007, 35, 495-516. [CrossRef]

32. Hanson, C.J.; Bootman, M.D.; Distelhorst, C.W.; Wojcikiewicz, R.J.; Roderick, H.L. Bcl-2 suppresses Ca2+ release through inositol 1,4,5-trisphosphate receptors and inhibits Ca2+ uptake by mitochondria without affecting ER calcium store content. Cell Calcium 2008, 44, 324-338. [CrossRef] [PubMed]

33. Fridman, J.S.; Lowe, S.W. Control of apoptosis by p53. Oncogene 2003, 22, 9030-9040. [CrossRef]

34. Wang, C.; Youle, R.J. The role of mitochondria in apoptosis*. Annu Rev. Genet. 2009, 43, 95-118. [CrossRef] [PubMed]

35. Ferrario, A.; Rucker, N.; Wong, S.; Luna, M.; Gomer, C.J. Survivin, a Member of the Inhibitor of Apoptosis Family, Is Induced by Photodynamic Therapy and Is a Target for Improving Treatment Response. Cancer Res. 2007, 67, 4989-4995. [CrossRef] [PubMed]

36. Wei, H.; Wei, S.; Gan, B.; Peng, X.; Zou, W.; Guan, J.L. Suppression of autophagy by FIP200 deletion inhibits mammary tumorigenesis. Genes. Dev. 2011, 25, 1510-1527. [CrossRef]

37. Krajarng, A.; Chulasiri, M.; Watanapokasin, R. Etlingera elatior Extract promotes cell death in B16 melanoma cells via downregulation of ERK and Akt signaling pathways. BMC Complementary Altern. Med. Vol. 2017, 17, 415. [CrossRef] [PubMed]

38. Lee, E.R.; Kim, J.Y.; Kang, Y.J.; Ahn, J.Y.; Kim, J.H.; Kim, B.W.; Choi, H.Y.; Jeong, M.Y.; Cho, S.G. Interplay between PI3K/Akt and MAPK signaling pathwaysin DNA-damaging drug-induced apoptosis. Biochim. Biophys. Acta 2006, 1763, 958-968. [CrossRef] [PubMed] 
39. Sharifi, M.N.; Mowers, E.E.; Drake, L.E.; Collier, C.; Chen, H.; Zamora, M.; Mui, S.; Macleod, K.F. Autophagy Promotes Focal Adhesion Disassembly and Cell Motility of Metastatic Tumor Cells through the Direct Interaction of Paxillin with LC3. Cell Rep. 2016, 15, 1660-1672. [CrossRef]

40. Meeran, S.M.; Katiyar, S.K. Cell cycle control as a basis for cancer chemoprevention through dietary agents. Front. Biosci. A J. Virtual Libr. 2008, 13, 2191-2202. [CrossRef] [PubMed]

41. Abdullah, S.; Abidin, S.A.Z.; Murad, N.A.; Makpol, S.; Ngah, W.Z.W.; Yusof, Y.A.M. Ginger extract (Zingiber officinale) triggers apoptosis and G0/G1 cells arrest in HCT 116 and HT 29 colon cancer cell lines. Afr. J. Biochem. Res. 2010, 4, 134-142.

42. El-Ashmawy, N.E.; Khedr, N.F.; El-Bahrawy, H.A.; Mansour, H.E.A. Ginger extract adjuvant to doxorubicin in mammary carcinoma: Study of some molecular mechanisms. Eur. J. Nutr. 2018, 57, 981-989. [CrossRef] [PubMed]

43. Elkady, A.I.; Hussein, R.A.E.H.; Abu-Zinadah, O.A. Differential control of growth, apoptotic activity and gene expression in human colon cancer cells by extracts derived from medicinal herbs, Rhazya strictaandZingiber officinaleand their combination. World J. Gastroenterol. 2014, 20, 15275-15288. [CrossRef]

44. Sehrawat, A.; Arlotti, J.A.; Murakami, A.; Singh, S.V. Zerumbone causes Bax- and Bak-mediated apoptosis in human breast cancer cells and inhibits orthotopic xenograft growth in vivo. Breast Cancer Res. Treat. 2012, 136, 429-441. [CrossRef] [PubMed]

45. Pashaei-Asl, R.; Pashaei-Asl, F.; Gharabaghi, P.M.; Khodadadi, K.; Ebrahimi, M.; Ebrahimie, E.; Pashaiasl, M. The Inhibitory Effect of Ginger Extract on Ovarian Cancer Cell Line; Application of Systems Biology. Adv. Pharm. Bull. 2017, 7, 241-249. [CrossRef]

46. Choudhury, D.; Das, A.; Bhattacharya, A.; Chakrabarti, G. Aqueous extract of ginger shows antiproliferative activity through disruption of microtubule network of cancer cells. Food Chem. Toxicol. 2010, 48, 2872-2880. [CrossRef]

47. Wang, G.; Li, X.; Huang, F.; Zhao, J.; Ding, H.; Cunningham, C.; Coad, J.E.; Flynn, D.C.; Reed, E.; Li, Q.Q. Antitumor effect of beta-elemene in non-small-cell lung cancer cells is mediated via induction of cell cycle arrest and apoptotic cell death. Cell. Mol. Life Sci. 2005, 62, 881-893. [CrossRef]

48. Liu, Y.; Whelan, R.J.; Pattnaik, B.R.; Ludwig, K.; Subudhi, E.; Rowland, H.; Claussen, N.; Zucker, N.; Uppal, S.; Kushner, D.M.; et al. Terpenoids from Zingiber officinale (Ginger) Induce Apoptosis in Endometrial Cancer Cells through the Activation of p53. PLoS ONE 2012, 7, e53178. [CrossRef]

49. Garg, H.; Suri, P.; Gupta, J.C.; Talwar, G.P.; Dubey, S. Survivin: A unique target for tumor therapy. Cancer Cell Int. 2016, 16, 1-14. [CrossRef]

50. Muller, P.A.J.; Vousden, K.H. p53 mutations in cancer. Nat. Cell Biol. 2013, 15, 2-8. [CrossRef]

51. Ansari, J.A.; Ahmad, M.K.; Khan, A.R.; Fatima, N.; Khan, H.J.; Rastogi, N.; Mishra, D.P.; Mahdi, A.A. Anticancer and Antioxidant activity of Zingiber officinale Roscoe rhizome. Indian J. Exp. Boil. 2016, 54, 767-773.

52. Lum, J.J.; Bauer, D.E.; Kong, M.; Harris, M.H.; Li, C.; Lindsten, T.; Thompson, C.B. Growth Factor Regulation of Autophagy and Cell Survival in the Absence of Apoptosis. Cell 2005, 120, 237-248. [CrossRef] [PubMed]

53. Scherz-Shouval, R.; Shvets, E.; Fass, E.; Shorer, H.; Gil, L.; Elazar, Z. Reactive oxygen species are essential for autophagy and specifically regulate the activity of Atg4. EMBO J. 2007, 26, 1749-1760. [CrossRef] [PubMed]

54. Nazim, U.M.; Jeong, J.-K.; Seol, J.-W.; Hur, J.; Eo, S.-K.; Lee, J.-H.; Park, S.-Y. Inhibition of the autophagy flux by gingerol enhances TRAIL-induced tumor cell death. Oncol. Rep. 2015, 33, 2331-2336. [CrossRef] [PubMed]

55. Luna-Dulcey, L.; Tomasin, R.; Naves, M.A.; Da Silva, J.A.; Cominetti, M.R. Autophagy-dependent apoptosis is triggered by a semi-synthetic [6]-gingerol analogue in triple negative breast cancer cells. Oncotarget 2018, 9, 30787-30804. [CrossRef] [PubMed]

56. Tsai, Y.; Xia, C.; Sun, Z. The Inhibitory Effect of 6-Gingerol on Ubiquitin-Specific Peptidase 14 Enhances Autophagy-Dependent Ferroptosis and Anti-Tumor in vivo and in vitro. Front. Pharmacol. 2020, 11, 598555. [CrossRef] [PubMed]

57. Karna, P.; Chagani, S.; Gundala, S.R.; Rida, P.C.; Asif, G.; Sharma, V.; Gupta, M.V.; Aneja, R. Benefits of whole ginger extract in prostate cancer. Br. J. Nutr. 2012, 107, 473-484. [CrossRef]

58. Akimoto, M.; Iizuka, M.; Kanematsu, R.; Yoshida, M.; Takenaga, K. Anticancer Effect of Ginger Extract against Pancreatic Cancer Cells Mainly through Reactive Oxygen Species-Mediated Autotic Cell Death. PLoS ONE 2015, 10, e0126605. [CrossRef]

59. Grivennikova, V.; Kozlovsky, V.S.; Vinogradov, A.D. Respiratory complex II: ROS production and the kinetics of ubiquinone reduction. Biochim. Biophys. Acta (BBA)-Bioenerg. 2017, 1858, 109-117. [CrossRef]

60. Dröge, W. Free Radicals in the Physiological Control of Cell Function. Physiol. Rev. 2002, 82, 47-95. [CrossRef]

61. Bachi, A.; Dalle-Donne, I.; Scaloni, A. Redox Proteomics: Chemical Principles, Methodological Approaches and Biological/Biomedical Promises. Chem. Rev. 2013, 113, 596-698. [CrossRef] [PubMed]

62. Storz, P. Reactive oxygen species in tumor progression. Front. Biosci 2005, 10, 1881-1896. [CrossRef]

63. Cao, X.-D.; Zheng, H.-M. Zerumbone inhibits prostate cancer cell viability and induces cell death by non-apoptotic pathway. Bangladesh J. Pharmacol. 2016, 11, 771. [CrossRef]

64. Park, E.J.; Pezzuto, J.M. Botanicals in cancer chemoprevention. Cancer Metastasis Rev. 2002, 21, 231-255. [CrossRef] [PubMed]

65. Danwilai, K.; Konmun, J.; Sripanidkulchai, B.-O.; Subongkot, S. Antioxidant activity of ginger extract as a daily supplement in cancer patients receiving adjuvant chemotherapy: A pilot study. Cancer Manag. Res. 2017, 9, 11-18. [CrossRef]

66. Nishida, N.; Yano, H.; Nishida, T.; Kamura, T.; Kojiro, M. Angiogenesis in cancer. Vasc. Health Risk Manag. 2006, 2, 213-219. [CrossRef]

67. Bussolino, F.; Mantovani, A.; Persico, G. Molecular mechanisms of blood vessel formation. Trends Biochem. Sci. 1997, 22, 251-256. [CrossRef]

68. Folkman, J. Tumor Angiogenesis: Therapeutic Implications. N. Engl. J. Med. 1971, 285, 1182-1186. [CrossRef] 
69. Niu, G.; Chen, X. Vascular endothelial growth factor as an anti-angiogenic target for cancer therapy. Curr. Drug Targets 2010, 11, 1000-1017. [CrossRef]

70. Wang, Z.; Dabrosin, C.; Yin, X.; Fuster, M.M.; Arreola, A.; Rathmell, W.K.; Generali, D.; Nagaraju, G.P.; El-Rayes, B.; Ribatti, D.; et al. Broad targeting of angiogenesis for cancer prevention and therapy. Semin. Cancer Biol. 2015, 35, S224-S243. [CrossRef]

71. Mukherjee, A.; Madamsetty, V.S.; Paul, M.K.; Mukherjee, S. Recent Advancements of Nanomedicine towards Antiangiogenic Therapy in Cancer. Int. J. Mol. Sci. 2020, 21, 455. [CrossRef]

72. Kim, S.O.; Kundu, J.K.; Shin, Y.K.; Prk, J.H.; Cho, M.H.; Kim, T.Y.; Surh, Y.J. [6]-Gingerol inhibits COX-2 expression by blocking the activation of p38 MAP kinase and NF-K B in phorbol ester-stimulated mouse skin. Oncogene 2005, 24, 2558-2567. [CrossRef]

73. Bashir, M.F.; Qadir, M.I. Effect of ginger extract on angiogenesis using CAM assay. Bangladesh J. Pharmacol. 2017, 12, 348. [CrossRef]

74. Brown, A.C.; Shah, C.; Liu, J.; Pham, J.T.; Zhang, J.G.; Jadus, M.R. Ginger's (Zingiber officinale Roscoe) inhibition of rat colonic adenocarcinoma cells proliferation and angiogenesis in vitro. Phytother Res. 2009, 23, 640-645. [CrossRef]

75. Pacifico, F.; Leonardi, A. NF-kappaB in solid tumors. Biochem. Pharm. 2006, 72, 1142-1152. [CrossRef]

76. Marie-Egyptienne, D.T.; Lohse, I.; Hill, R.P. Cancer stem cells, the epithelial to mesenchymal transition (EMT) and radioresistance: Potential role of hypoxia. Cancer Lett. 2013, 341, 63-72. [CrossRef] [PubMed]

77. Ricci-Vitiani, L.; Pilozzi, E.L.D. Identification and expansion of human colon-cancer-initiating cells. Nature 2007, 445, 111-115. [CrossRef]

78. Todaro, M.; Francipane, M.G.; Medema, J.P.; Stassi, G. Colon Cancer Stem Cells: Promise of Targeted Therapy. Gastroenterology 2010, 138, 2151-2162. [CrossRef] [PubMed]

79. Zeuner, A.; Todaro, M.; Stassi, G.; De Maria, R. Colorectal Cancer Stem Cells: From the Crypt to the Clinic. Cell Stem Cell 2014, 15, 692-705. [CrossRef]

80. Sengupta, A.; Cancelas, J.A. Cancer stem cells: A stride towards cancer cure? J. Cell. Physiol. 2010, 225, 7-14. [CrossRef] [PubMed]

81. Kozovska, Z.; Gabrisova, V.; Kucerova, L. Colon cancer: Cancer stem cells markers, drug resistance and treatment. Biomed. Pharmacother. 2014, 68, 911-916. [CrossRef] [PubMed]

82. Hollier, B.G.; Evans, K.; Mani, S.A. The Epithelial-to-Mesenchymal Transition and Cancer Stem Cells: A Coalition Against Cancer Therapies. J. Mammary Gland. Biol. Neoplasia 2009, 14, 29-43. [CrossRef] [PubMed]

83. Zhou, P.; Li, B.; Liu, F.; Zhang, M.; Wang, Q.; Liu, Y.; Yao, Y.; Li, D. The epithelial to mesenchymal transition (EMT) and cancer stem cells: Implication for treatment resistance in pancreatic cancer. Mol. Cancer 2017, 16, 1-11. [CrossRef] [PubMed]

84. Martínez-Ramírez, A.S.; Díaz-Muñoz, M.; Butanda-Ochoa, A.; Vázquez-Cuevas, F.G. Nucleotides and nucleoside signaling in the regulation of the epithelium to mesenchymal transition (EMT). Purinergic Signal. 2016, 13, 1-12. [CrossRef]

85. Suryawanshi, A.; Tadagavadi, R.K.; Swafford, D.; Manicassamy, S. Modulation of Inflammatory Responses by Wnt/beta-Catenin Signaling in Dendritic Cells: A Novel Immunotherapy Target for Autoimmunity and Cancer. Front. Immunol. 2016, 7, 460. [CrossRef]

86. Peng, Y.; Zhang, X.; Feng, X.; Fan, X.; Jin, Z. The crosstalk between microRNAs and the Wnt/beta-catenin signaling pathway in cancer. Oncotarget 2017, 8, 14089-14106. [CrossRef]

87. Kinzler, K.W.; Vogelstein, B. Lessons from Hereditary Colorectal Cancer. Cell 1996, 87, 159-170. [CrossRef]

88. Kim, V.N. MicroRNA biogenesis: Coordinated cropping and dicing. Nat. Rev. Mol. Cell Biol. 2005, 6, 376-385. [CrossRef]

89. Ghahhari, N.M.; Babashah, S. Interplay between microRNAs and WNT/beta-catenin signalling pathway regulates epithelialmesenchymal transition in cancer. Eur. J. Cancer 2015, 51, 1638-1649. [CrossRef]

90. Dermani, F.K.; Amini, R.; Saidijam, M.; Pourjafar, M.; Saki, S.; Najafi, R. Zerumbone inhibits epithelial-mesenchymal transition and cancer stem cells properties by inhibiting the $\beta$-catenin pathway through miR-200c. J. Cell. Physiol. 2018, 233, 9538-9547. [CrossRef]

91. Martin, A.C.B.; Fuzer, A.M.; Becceneri, A.B.; Da Silva, J.A.; Tomasin, R.; DeNoyer, D.; Kim, S.-H.; McIntyre, K.A.; Pearson, H.B.; Yeo, B.; et al. [10]-gingerol induces apoptosis and inhibits metastatic dissemination of triple negative breast cancer in vivo. Oncotarget 2017, 8, 72260-72271. [CrossRef]

92. Akiyama, S.; Chen, Z.S.; Kitazono, M.; Sumizawa, T.; Furukawa, T.; Aikou, T. Mechanisms for resistance to anticancer agents and the reversal of the resistance. Hum. Cell 1999, 12, 95-102. [PubMed]

93. Choi, Y.H.; Yu, A.M. ABC transporters in multidrug resistance and pharmacokinetics, and strategies for drug development. Curr Pharm Des. 2014, 20, 793-807. [CrossRef] [PubMed]

94. Liu, Y.-H.; Di, Y.-M.; Zhou, Z.-W.; Mo, S.-L.; Zhou, S.-F. Multidrug resistance-associated proteins and implications in drug development. Clin. Exp. Pharmacol. Physiol. 2010, 37, 115-120. [CrossRef]

95. Liu, C.-M.; Kao, C.-L.; Tseng, Y.-T.; Lo, Y.-C.; Chen, C.-Y. Ginger Phytochemicals Inhibit Cell Growth and Modulate Drug Resistance Factors in Docetaxel Resistant Prostate Cancer Cell. Molecules 2017, 22, 1477. [CrossRef] [PubMed]

96. Chen, H.; Lv, L.; Soroka, D.; Warin, R.F.; Parks, T.A.; Hu, Y.; Zhu, Y.; Chen, X.; Sang, S. Metabolism of [6]-Shogaol in Mice and in Cancer Cells. Drug Metab. Dispos. 2012, 40, 742-753. [CrossRef]

97. Asami, A.; Shimada, T.; Mizuhara, Y.; Asano, T.; Takeda, S.; Aburada, T.; Miyamoto, K.; Aburada, M. Pharmacokinetics of [6]-shogaol, a pungent ingredient of Zingiber officinale Roscoe (Part I). J. Nat. Med. 2010, 64, 281-287. [CrossRef]

98. Dong, Y.; Tu, J.; Zhou, Y.; Zhou, X.H.; Xu, B.; Zhu, S.Y. Silybum marianum oil attenuates oxidative stress and ameliorates mitochondrial dysfunction in mice treated with D-galactose. Pharmacogn. Mag. 2014, 10, 92-S99. [CrossRef] 
99. Yi, C.; Zhong, H.; Tong, S.; Cao, X.; Firempong, C.K.; Liu, H.; Fu, M.; Yang, Y.; Feng, Y.; Zhang, H.; et al. Enhanced oral bioavailability of a sterol-loaded microemulsion formulation of Flammulina velutipes, a potential antitumor drug. Int. J. Nanomed. 2012, 7, 5067-5078.

100. Hou, J.; Sun, E.; Sun, C.; Wang, J.; Yang, L.; Jia, X.B.; Zhang, Z.H. Improved oral bioavailability and anticancer efficacy on breast cancer of paclitaxel via Novel Soluplus((R))-Solutol((R)) HS15 binary mixed micelles system. Int. J. Pharm. 2016, 512, 186-193. [CrossRef]

101. Wang, G.; Wang, J.-J.; Chen, X.-L.; Du, L.; Li, F. Quercetin-loaded freeze-dried nanomicelles: Improving absorption and anti-glioma efficiency in vitro and in vivo. J. Control. Release 2016, 235, 276-290. [CrossRef] [PubMed]

102. Zhang, H.; Wang, Q.; Sun, C.; Zhu, Y.; Yang, Q.; Wei, Q.; Chen, J.; Deng, W.; Adu-Frimpong, M.; Yu, J.; et al. Enhanced Oral Bioavailability, Anti-Tumor Activity and Hepatoprotective Effect of 6-Shogaol Loaded in a Type of Novel Micelles of Polyethylene Glycol and Linoleic Acid Conjugate. Pharmaceutics 2019, 11, 107. [CrossRef] [PubMed]

103. Wee, L.H.; Morad, N.A.; Aan, G.J.; Makpol, S.; Ngah, W.Z.W.; Yusof, Y.A.M. Mechanism of Chemoprevention against Colon Cancer Cells Using Combined Gelam Honey and Ginger Extract via mTOR and Wnt/beta-catenin Pathways. Asian Pac. J. Cancer Prev. 2015, 16, 6549-6556. [CrossRef] [PubMed]

104. Vemuri, S.K.; Banala, R.R.; Subbaiah, G.P.V.; Srivastava, S.K.; Reddy, A.G.; Malarvili, T. Anti-cancer potential of a mix of natural extracts of turmeric, ginger and garlic: A cell-based study. Egypt. J. Basic Appl. Sci. 2017, 4, 332-344. [CrossRef]

105. Yekta, Z.P.; Ebrahimi, S.M.; Hosseini, M.; Nasrabadi, A.N.; Sedighi, S.; Surmaghi, M.-H.S.; Madani, H. Ginger as a miracle against chemotherapy-induced vomiting. Iran. J. Nurs. Midwifery Res. 2012, 17, 325-329.

106. Lete, I.; Allue, J. The Effectiveness of Ginger in the Prevention of Nausea and Vomiting during Pregnancy and Chemotherapy. Integr Med. Insights 2016, 11, 11-17. [CrossRef] 